\title{
Polybrominated diphenyl ethers (PBDEs) in eggshells of the Southern Ground-Hornbill (Bucorvus leadbeateri) and Wattled Crane (Bugeranus carunculatus) in South Africa
}

\author{
Adegbenro P. Daso ${ }^{*}$, Jonathan O. Okonkwo², Ray Jansen², Patricia BC. Forbes ${ }^{1}$, Antoinette \\ Kotzé $^{3}$, Egmont R. Rohwer ${ }^{1}$
}

${ }^{1}$ Department of Chemistry, Faculty of Natural and Agricultural Sciences, University of Pretoria, Private Bag X20, Hatfield 0028, Pretoria, South Africa.

${ }^{2}$ Department of Environmental, Water and Earth Sciences, Tshwane University of Technology, 175 Nelson Mandela Drive, Private Bag X680, Arcadia, Pretoria, South Africa.

${ }^{3}$ National Zoological Gardens of South Africa, P.O. Box 754, Pretoria 0001, South Africa

*Corresponding author: Tel: +27789027213, +27746546510; Fax: +27124204687;

adegbenrop@gmail.com; adegbenrop@yahoo.com

\begin{abstract}
This study was undertaken to assess the levels of eight PBDE congeners, namely: PBDE-17, 47, 100, 99, 154, 153, 183 and 209 in eggshells of Southern Ground-Hornbill (SGH) Bucorvus leadbeateri and Wattled Crane (WC) Bugeranus carunculatus obtained from different nesting sites within the eastern savanna of Limpopo Province and the midlands of KwaZulu-Natal, respectively. Analyses were performed using gas chromatography-mass spectrometry employing the electron impact ionization technique. The results obtained indicated that the lower brominated congeners were predominant in both species. The total PBDEs ranged between not detected (ND) to $264 \mu \mathrm{g} \mathrm{g}^{-1}$ lipid weight and 5.98 to $7146 \mu \mathrm{g} \mathrm{g}^{-1}$ lipid weight in the SGH and WC samples, respectively. More so, the mean recoveries of the ${ }^{13} \mathrm{C}$-labelled surrogate standards ranged between $40 \%$ (PBDE-100) to $136 \%$ (PBDE-99). The potential hazards to these birds via PBDEs exposure were evaluated by determining the hazard quotients (HQs) by employing the established Lowest Observed Effect Level (LOEL) values associated with impaired pipping and hatching success as well as that associated with impaired reproduction. HQs values varying from 0.58 to 0.94 and 27.71 to 45.27 , respectively were obtained for SGH and WC species. This implies that the SGH populations are exposed to low to moderate hazards, while the WC populations are susceptible to high hazards. Considering the potential threats posed by PBDEs, particularly to the WC species, it is likely that exposure to the current environmental levels of PBDEs by these birds may contribute to their reduced breeding success and declining population trends.
\end{abstract}

Keywords: PBDEs; eggshell; Southern Ground-Hornbill; Wattled Crane; reproduction. 


\section{Introduction}

Both the Southern Ground-Hornbill (Bucorvus leadbeateri) and the Wattled Crane (Bugeranus carunculatus) are considered as large avian terrestrial and semi terrestrial species that have been classified as vulnerable and critically endangered in South Africa by the International Union for the Conservation of Nature (IUCN, 2013). Both species occur sporadically throughout the southern Africa sub region.

The SGH is a monogamous, co-operative breeder (Kemp, 1995a; Knight, 1990) with a relatively low breeding success rearing on average, only one chick every 9.3 years (Kemp 1988). This highly territorial species (Theron, et al. in press) has effectively been eliminated from much of its historical range within savanna and grassland habitats primarily as a result of habitat destruction (Barnes, 2000; Kemp, 1987) and persecution for its habit of breaking residential and vehicle windows (Vernon, 1982; Forsberg, 1994). The species is exposed to poisoning whilst foraging on a variety of invertebrate prey items and other larger prey such as amphibians, reptiles, birds and even young hares (Kemp \& Kemp, 1977; Knight, 1990). With a slow population turnover, the species can be susceptible to isolated stochastic events such as environmental contamination from potentially harmful pollutants.

Even more concerning is the WC population that has dropped dramatically in recent years. The global population is estimated at less than 8000 individuals (Beilfuss et al., 2003). This population crash has been attributed primarily to the destruction of their primary habitat being shallow permanent wetlands that are under threat of degradation throughout the species range (Tarboton, 1984; Barnes, 2000, Beilfuss et al., 2003). The WC is also monogamous but a solitary nester (West, 1963; Tarboton, 2001) where breeding success has been recorded as highly variable between locations but relatively unsuccessful (for a review see Allan, 2005). These breeding pairs are mostly sedentary on small permanent wetlands but occasional large scale movements have been recorded (Konrad, 1981) and a number of records have indicated seasonal movements between provinces within South Africa (McCann et al., 2001). Within wetlands, this species forages primarily on tubers and grass seeds (Bento, 2002) and occasionally within cultivated fields and pastures (Tarboton, 1984; Maozeka, 1993). This species is also highly susceptible to environmental contamination as they opportunistically prey upon small fish (Douthwaite, 1974) and frogs (Rogers \& Rogers 1999) within wetlands; an environment that is known for bioaccumulation of toxins.

In an attempt to reverse the potential extinction of these two bird species in South Africa, two conservation initiatives, notably the Wattled Crane Recovery Programme (WCRP) and Mabula Ground Hornbill Project were initiated. The objectives of these projects include the collection of second eggs and hand-rearing of the chicks. The successful re-introduction of these captive and artificially bred birds into the wild is an important element of the conservation efforts.

A number of threats for both species have been clearly identified in the literature and in the recovery programmes, however, the possible effects associated with exposure to harmful persistent organic pollutants to these two bird species in South Africa are yet to be fully investigated. Many generally 
used chemical substances are known to cause endocrine disruption as well as reproductive dysfunctional effects in exposed subjects. Polybrominated diphenyl ethers (PBDEs), which are employed as additive flame-retardants in various consumer products, including plastics, furniture, computers, synthetic textiles, electrical and electronic appliances, amongst others, have been implicated as one of the emerging environmental pollutants in recent years (Verreault et al., 2006; Henny et al., 2009; Marteinson et al., 2011; Daso et al., 2012; 2013a; Kefeni and Okonkwo, 2012; Olukunle et al., 2012).

Due to their structural resemblance with certain thyroid hormones, these chemicals are able to mimic these essential hormones, thus interfering with the normal functioning and expression in the body (Kirkegaard et al., 2011). These systemic imbalances caused by the presence of PBDEs, especially the lower brominated congeners in exposed subjects, have been widely reported in various toxicological studies resulting in notable effects such as impaired reproduction, impaired pipping, endocrine disruption, amongst others (Lema et al., 2008; Henny et al., 2009; Chevier et al., 2010). In fact, a recent study reported the potential of PBDE-99 to initiate a prolong delay in the timing of reproduction in Zebra finch (Eng et al., 2013). The study went further to indicate that disruption in the reproductive system as a result of PBDE-99 contamination was observed. Interestingly, most of the health defects associated with exposure to PBDEs are dose-dependent (Lema et al., 2007). Therefore, it is necessary to ascertain the levels of these pollutants in different habitats and conditions, most especially in an avian habitat for a thorough understanding of any harmful effects on these threatened species. In South Africa, with the exception of the works of Polder et al (2008) who reported on the levels of PBDEs and HBCDs on the eggs of Peregrine falcons as well as Quinn et al. (2011) and Bouwman et al. (in press) who assessed PBDEs together with other organic pollutants in other bird species, no record of the evaluation of PBDEs in the investigated bird species was found in the literature.

This is a first attempt to assess the levels of 8 PBDE congeners in hatched eggshells of SGH and WC collected from the Kruger National Park and the midlands of KwaZulu-Natal Province, respectively. The aim was to assess the concentrations of PBDEs in the eggshells of these species, as both are listed as vulnerable or critically endangered, respectively. The analysis of PBDEs in these samples is an important measure to determine their exposure to PBDEs where we aim to explain possible factors contributing to their decline in population.

\section{Materials and methods}

\subsection{Chemicals and materials}

All organic solvents ( $n$-hexane, dichloromethane, and isooctane (SupraSolv ${ }^{\circledR}$ grade)) were purchased from Merck (Modderfontein, South Africa). Surrogate standards $\left({ }^{13} \mathrm{C}\right.$-labelled BDE congeners PBDE-28, 47, 100, 99, 154, 153, 183 and 209) as well as unlabeled native BDE congeners - PBDE17, 47, 100, 99, 154, 153, 183 and 209 were produced by Cambridge Isotope Laboratories (CIL) (Andover, MA, USA). These standards were locally supplied by Industrial Analytical (Pty) (Midrand (Gauteng), South Africa). Florisil $(60-100 \mathrm{~mm}$ ) was supplied by Sigma-Aldrich (Aston Manor 
(Gauteng), South Africa). High purity gases (Helium - 99.999\%; nitrogen 99.999\%) were purchased from by Afrox (Pty) Ltd. (Pretoria, South Africa).

\subsection{Sample collection and preparation}

SGH eggshells $(N=9)$ were collected following hatching from nine nest sites within the Kruger National Park during the 2012 and 2013 breeding seasons. The Kruger National Park is a longstanding large National Park on the far north eastern border of South Africa. It is far removed from any large cities and industrial activity. However, in recent years a number of large coal and copper mines have become established on its western boarder and this has also led to further expansion of the town of Phalaborwa. Six WC eggshells were also collected from nest sites located within the KwaZulu-Natal midlands (within the vicinity of the town of Nottingham Road and the Underberg) during 2011. For both species, the eggshells were removed from the nest once the chicks had successfully hatched. If for some reason the egg failed to hatch, the entire egg was removed from the nest.

The detailed geographical description of the sampling sites is presented in Figure 1. The midlands of KwaZulu-Natal are dominated by montane grasslands primarily used for cattle and sheep pasture agriculture. This area is a popular tourist destination on route to the Drakensberg mountain range or the South Coast.

All the egg samples specifically contained the eggshell, and leftovers of dried egg membranes containing some dried albumin materials. Each egg sample was kept in a self-sealing polyethylene bag and stored in a refrigerator until analysis. During sample preparation, the shells of the WC egg samples were carefully separated from the dried membrane and the albumin materials. These components were grounded separately and stored in polyethylene bags until further analysis. In contrast, the eggshells of the SGH are thinner and more fragile thus making the separation of the dried egg membranes and some leftovers of dried albumin materials somewhat difficult. As a result, each sample was treated as one ground mass. A sequential ultrasonic-assisted extraction technique was employed for the isolation of the target compounds from each of the samples. In this case, about $1-2 \mathrm{~g}$ of dried grounded egg sample (eggshell or dried albumen) was carefully weighed and transferred into a thoroughly clean extraction glass container. Due to the limited sample quantities, measurements were performed in duplicate for all the analysed samples. Prior to the extraction, each sample was spiked with $20 \mu \mathrm{L}$ of ${ }^{13} \mathrm{C}$-labelled BDE surrogate standard with a concentration of $1 \mu \mathrm{g} / \mathrm{mL}$ (PBDE 28, 47, 100, 99, 154, 153 and 183) and $10 \mu \mathrm{g} / \mathrm{mL}$ for PBDE-209. The samples were extracted with $5 \mathrm{~mL}$ hexane:dichloromethane $(1: 1, \mathrm{v} / \mathrm{v})$ for $60 \mathrm{~min}$ at a maximum temperature of $65{ }^{\circ} \mathrm{C}$. Upon cooling, the extracted samples were centrifuged at 3,000 rpm for $10 \mathrm{~min}$. The clear supernatant was decanted into a clean $100 \mathrm{~mL}$ round bottom flask. The extracted samples were subsequently extracted with $5 \mathrm{~mL}$ of the extraction solvents for additional $30 \mathrm{~min}$. under the same temperature conditions. Extracts obtained were similarly treated as previously described. Finally, the third extraction step was carried out using $2 \mathrm{~mL}$ of the extraction solvents for additional 30 min under similar temperature conditions. The combined extract obtained was concentrated using a rotary evaporator set at $45{ }^{\circ} \mathrm{C}$ and operated under vacuum to about $1 \mathrm{~mL}$. This was further subjected to 


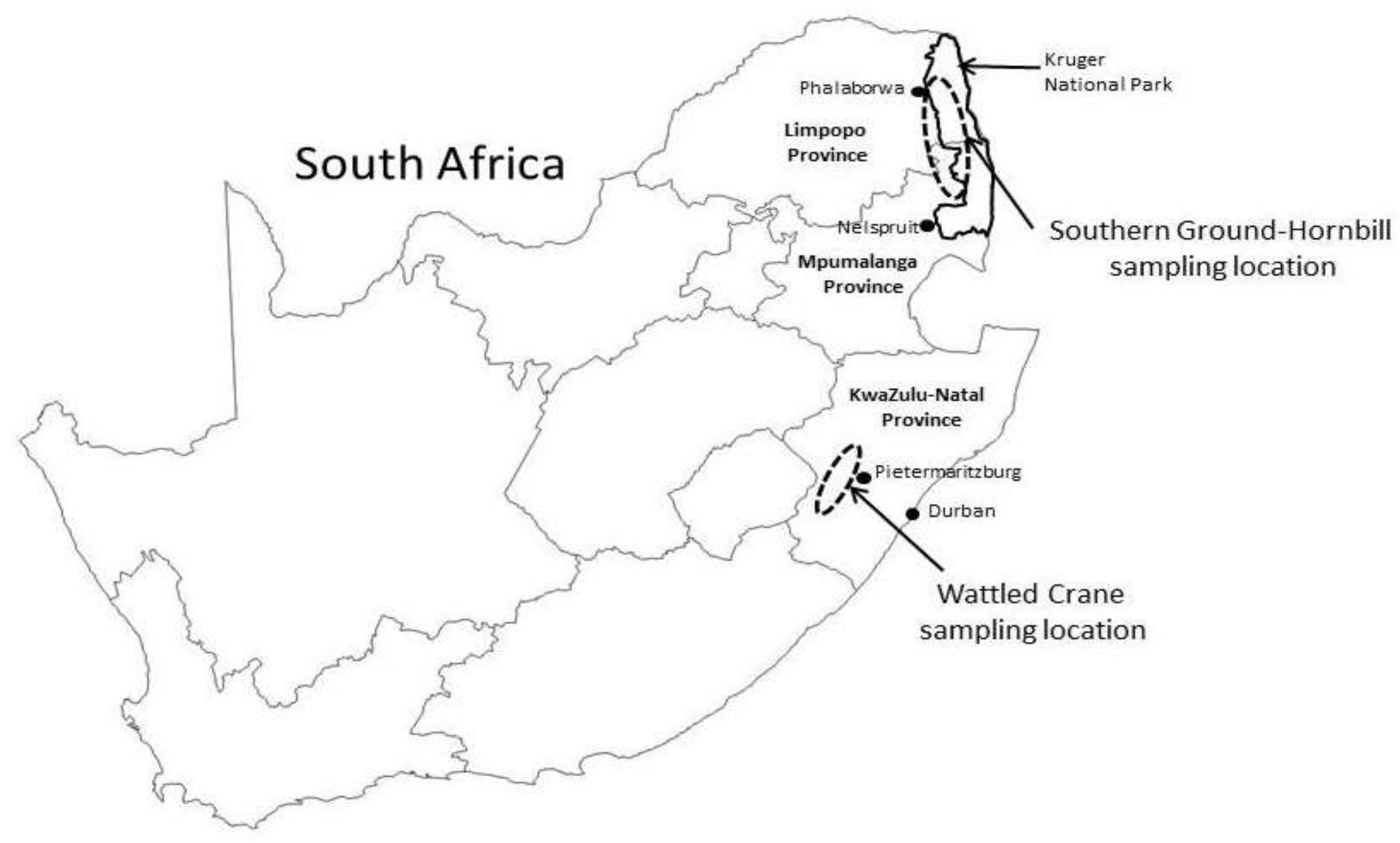

Figure 1: Map of the study area indicating the sampling locations within the three South African Provinces. 
column chromatography employing $2 \mathrm{~g}$ of Florisil as the sorbent material. The packed column was pre-conditioned with $10 \mathrm{~mL}$ of $\mathrm{n}$-hexane to remove trapped air as well as background contaminants within the column. The concentrated extract was then quantitatively transferred into the column and eluted with $10 \mathrm{~mL}$ of $\mathrm{n}$-hexane. The eluate was concentrated to about $1 \mathrm{~mL}$ using a rotary evaporator. Further concentration of extract was done under a gentle stream of pure nitrogen to near dryness. The extract was then reconstituted with $500 \mu \mathrm{L}$ of isooctane. The prepared samples were then kept in the refrigerator until the final instrumental analysis.

\subsection{Instrumental analysis}

The quantitative estimation of all the target compounds was performed using an Ultra-trace 2010 Shimadzu GC equipped with QP 2010 Ultra mass spectrometer operated in El mode. The chromatographic separation of these compounds was achieved using ZB-5 MS (15 m, $0.25 \mathrm{~mm}$ i.d., $0.25 \mu \mathrm{m}$ film thickness) capillary column. The optimal conditions employed for the GC-EI-MS instrument are shown in Table 1. To enhance the sensitivity of the instrument and to overcome the

Table 1: Optimised GC-EI-MS conditions employed for PBDEs analysis

\begin{tabular}{ll}
\hline Parameters & Optimum conditions \\
\hline GC parameters & \\
Injection volume & $1 \mu$ \\
Injection mode & Splitless \\
Flow control mode & Linear velocity \\
Injector temperature & $270^{\circ} \mathrm{C}$ \\
Linear velocity & $80.0 \mathrm{~cm} / \mathrm{sec}$ \\
Column flow & $2.33 \mathrm{ml} / \mathrm{min}$. \\
Purge flow & $1.0 \mathrm{ml} / \mathrm{min}$. \\
Equilibrium time & $3.0 \mathrm{~min}$. \\
Sampling time & $1.00 \mathrm{~min}$. \\
Oven temperature programming & $90^{\circ} \mathrm{C}$ held for 1.0 min., ramped $@ 40^{\circ} \mathrm{C} / \mathrm{min}$. to \\
& $200^{\circ} \mathrm{C}$, ramped $@ 25^{\circ} \mathrm{C} / \mathrm{min}$ to $250^{\circ} \mathrm{C}$, ramped $@$ \\
& $7.5^{\circ} \mathrm{C} / \mathrm{min}$ to $310^{\circ} \mathrm{C}$ held for $5 \mathrm{~min}$. \\
& \\
MS parameters & $250^{\circ} \mathrm{C}$ \\
lon source temperature & $280^{\circ} \mathrm{C}$ \\
Interface temperature & $2.0 \mathrm{~min}$. \\
Solvent cut time & $\mathrm{SIM}$ \\
Acquisition mode & $\mathrm{El}$ \\
lonisation method & $200-1000 \mathrm{amu}$ \\
MS library scan range & \\
\hline
\end{tabular}

inherent problems of interfering co-extractants, the MS acquisition was carried out in selected ion monitoring (SIM) mode. In this case, a target ion and two reference ions were selected for each PBDE congener as well as surrogate standards for their identification and quantification. The details of the selected target and reference ions for both the target compounds and the surrogate standards are presented in Supplementary Table S1.

The quantification of all the target compounds, which was based on peak area, was done using external calibration techniques. This was done using five to eight calibration levels $(1,5,10,25,50$, 
$100,200,500$ and $1000 \mathrm{ng} / \mathrm{mL}$ ) for all PBDE congeners. The linearity $\left(R^{2}\right)$ of the calibration plots for each target analyte was greater than 0.995 except for PBDE-209, which was 0.978.

The lipid content of the egg samples was determined by gravimetric analysis. Lipid from each sample was extracted using an ultrasonic-assisted extraction technique where $n$-hexane was employed as the extraction solvent. The extract obtained was transferred into a pre-weighed glass container. The solvent was thereafter evaporated and the lipid content was subsequently determined.

\subsection{Quality control and quality assurance}

To avoid the possible photodegradation of the higher brominated PBDE congeners, sample containers employed were either amber coloured or were wrapped with aluminium foil. Reagent blanks were also analysed together with the samples to assess potential contributions to the PBDE levels from reagent contamination. Detectable levels found in the blanks were subtracted from results obtained for the samples. To assess the accuracy of the method employed, the recoveries of the spiked ${ }^{13} \mathrm{C}$-labelled surrogate standards were evaluated. As shown in Table 2, the mean recoveries ranged from $40 \%$ (PBDE-100) to 136\% (PBDE-99). Consequently, all the results obtained were recovery corrected. The limit of detection (LOD) is defined as three times the standard deviation of the peak area divided by the slope of the calibration curve. The LOD values ranged from 0.03 (PBDE-47) to $8.88 \mathrm{ng} \mathrm{g}^{-1}$ (PBDE-183).

\section{Results and discussion}

\subsection{Inter-species variations in PBDE levels}

The eggshell as well as the dried albumen samples obtained from the two investigated bird species were analysed for PBDEs in this study. Conversely, due to the relatively thin and fragile nature of the eggshells of the SGH, each eggshell sample was treated as one ground mass. A representative subsample was, thereafter, taken from the homogenised sample for the analysis. The concentrations of the PBDE congeners in these samples based on extractable lipid weight basis are presented in Table 2.

Based on the occurrence of these congeners in the analysed samples, some notable distinctions amongst the two different bird species investigated were observed. While it appeared that both species could significantly accumulate the lower PBDE congeners, there was an apparent difference in their abilities to accumulate the higher brominated congeners. Interestingly, PBDE-183 as well as PBDE-209 was not detected in eggshells of the SGH, whereas both congeners were detected in three and one WC samples, respectively. In fact, these congeners were mostly detected in the dried albumen of the analysed samples probably signifying their preferential affinities to the albumin materials of their respective eggshell samples. Surprisingly, PBDE-209 contributed about $47 \%$ to the total PBDEs in the only sample in which it was found. PBDE concentrations found in eggshells of these birds are a much greater than expected as sampling sites are considered rural and far from any large cities or industrial activities. More so, the frequency and the congener profile of the target compounds were somewhat inconsistent amongst the bird species. Since these eggshells were 
Table 2: Mean concentrations ( $\mu \mathrm{g} / \mathrm{g}$, lipid weight) of PBDE congeners obtained from the analysis of eggshell samples of Southern Ground-Hornbill and Wattled Crane in South Africa.

\begin{tabular}{|c|c|c|c|c|c|c|c|c|c|c|c|}
\hline $\mathbf{S} / \mathbf{N}$ & $\begin{array}{l}\text { Sampling } \\
\text { sites }\end{array}$ & $\sum$ \&PBDEs & PBDE-17 & PBDE-47 & PBDE-100 & PBDE-99 & PBDE-154 & PBDE-153 & PBDE-183 & PBDE-209 & \% Lipid content ${ }^{2}$ \\
\hline \multicolumn{12}{|c|}{ Southern Ground-Hornbills } \\
\hline 1 & LK & 102.39 & n.d. & 5.84 & 69.86 & 3.44 & n.d. & 23.25 & n.d. & n.d. & 0.23 \\
\hline 2 & LK & 0 & n.d. & n.d. & n.d. & n.d. & n.d. & n.d. & n.d. & n.d. & 0.05 \\
\hline 3 & LK & 0.77 & 0.77 & n.d. & n.d. & n.d. & n.d. & n.d. & n.d. & n.d. & 1.72 \\
\hline 4 & LK & 8.05 & 2.45 & 1.90 & n.d. & 3.70 & n.d. & n.d. & n.d. & n.d. & 0.25 \\
\hline 5 & LK & 6.49 & 5.70 & 0.79 & n.d. & n.d. & n.d. & n.d. & n.d. & n.d. & 0.17 \\
\hline 6 & $\mathrm{TN}$ & 0.98 & 0.93 & 0.05 & n.d. & n.d. & n.d. & n.d. & n.d. & n.d. & 2.05 \\
\hline 7 & ALP & 264.17 & 0.58 & 215.36 & 14.31 & 33.91 & n.d. & n.d. & n.d. & n.d. & 0.66 \\
\hline 8 & JNK PNR & 35.61 & n.d. & n.d. & 24.63 & 2.58 & n.d. & 8.40 & n.d. & n.d. & 0.50 \\
\hline 9 & RRT & 1.26 & n.d. & n.d. & n.d. & 1.26 & n.d. & n.d. & n.d. & n.d. & 0.53 \\
\hline Mean & & 46.63 & 1.16 & 24.88 & 12.09 & 4.99 & - & 3.52 & - & - & 0.68 \\
\hline SEM & & 29.36 & 0.63 & 23.82 & 7.80 & 3.65 & - & 2.63 & - & - & 0.24 \\
\hline \multicolumn{12}{|c|}{ Wattled Cranes (eggshell) } \\
\hline 1 & RFNR & 10.43 & 1.63 & 0.04 & 8.77 & n.d. & n.d. & n.d. & n.d. & n.d. & 0.06 \\
\hline 2 & HWNR & 11.36 & 0.18 & 0.21 & n.d. & n.d. & n.d. & n.d. & 11.00 & n.d. & 1.26 \\
\hline 3 & IL & 0 & n.d. & n.d. & n.d. & n.d. & n.d. & n.d. & n.d. & n.d. & 0.44 \\
\hline 4 & MK & 2.49 & n.d. & n.d. & n.d. & 2.49 & n.d. & n.d. & n.d. & n.d. & 0.11 \\
\hline 5 & YWK & 8.51 & 6.28 & 2.23 & n.d. & n.d. & n.d. & n.d. & n.d. & n.d. & 0.12 \\
\hline 6 & CWU & 451.81 & n.d. & 1.32 & 440.76 & 9.73 & n.d. & n.d. & n.d. & n.d. & 0.13 \\
\hline Mean & & 80.77 & 1.35 & 0.63 & 74.92 & 2.04 & - & - & 1.83 & - & 0.36 \\
\hline SEM & & 74.23 & 1.02 & 0.38 & 73.18 & 1.59 & - & - & 1.83 & - & 0.19 \\
\hline \multicolumn{12}{|c|}{ Wattled Crane (dried albumen) } \\
\hline 1 & RFNR & 7145.73 & 11.17 & 9.85 & 4910.43 & 2058.58 & n.d. & n.d. & 155.71 & n.d. & 1.72 \\
\hline 2 & HWNR & 0.27 & 0.26 & 0.09 & n.d. & n.d. & n.d. & n.d. & n.d. & n.d. & 5.46 \\
\hline 3 & IL & 5.98 & 0.55 & 0.17 & n.d. & 3.82 & n.d. & 1.43 & n.d. & n.d. & 0.87 \\
\hline 4 & MK & 28.16 & 0.68 & n.d. & 26.59 & 0.90 & n.d. & n.d. & n.d. & n.d. & 3.08 \\
\hline 5 & YWK & 1091.75 & 490.68 & 1.66 & 106.34 & 113.68 & n.d. & n.d. & 379.38 & n.d. & 0.13 \\
\hline 6 & CWU & 141.04 & n.d. & 0.76 & 18.71 & 55.92 & n.d. & n.d. & n.d. & 65.65 & 4.40 \\
\hline Mean & & 1402.16 & 83.89 & 2.08 & 843.68 & 372.15 & - & 0.24 & 89.18 & 10.94 & 2.61 \\
\hline SEM & & 1161.58 & 81.38 & 1.58 & 813.51 & 337.78 & - & 0.24 & 63.36 & 10.94 & 0.85 \\
\hline $\begin{array}{l}\text { Recovery } \\
(\%)\end{array}$ & - & - & $76.38^{\mathrm{b}}$ & 74.96 & 40.00 & 135.94 & 50.74 & 76.25 & 62.16 & 104.50 & - \\
\hline
\end{tabular}


collected from several nesting sites from different areas, it would be reasonable to speculate that the observed levels were probably a reflection of the degree of exposure of the individual bird as well as the local conditions of their respective habitats. PBDE-47 was the predominant congener in the eggshells of the SGH contributing more than $50 \%$ to the overall PBDEs in most cases, while PBDE100 was the most dominant congener found in WC samples contributing more than $62 \%$ to the overall PBDEs. Generally, the patterns assumed by the target compounds in both species are as follows: PBDE-47 > PBDE-100 > PBDE-99 > PBDE-153 > PBDE-17 > PBDE-183 = PBDE-154 = PBDE-209 and PBDE-100 > PBDE-99 > PBDE-183 > PBDE-17 > PBDE-209 > PBDE-47 > PBDE-153 > PBDE154 for the SGH and WC samples, respectively. Considering the potential toxic effects often exerted on the reproductive system of exposed test animals by PBDE-47, 100 and 99, the prevalence of these congeners in the analysed eggshell samples is cause for concern.

Given the fact that the global population of these birds is rapidly declining, particularly the WC with their present world population being estimated at 7,700 individuals (Pittman, 2007), the underlying cause of these trends need to be unraveled. The declining trend in the population of these birds has been attributed to several factors, including habitat destruction, human interferences leading to declining breeding success, amongst others. The continued decline in population of these birds, especially within their isolated habitats suggests that factors other than those previously identified might be contributing to the decline.

Wetlands play a significant role in the natural restoration of the water quality of most adjoining water bodies. As such, wetlands act as natural filters or sinks to a number of persistent organic pollutants. In South Africa, most wetlands are replenished with water from varying sources. Contributions of the discharges of large quantities of partially treated, untreated and treated effluents as well as the intrusion of grey water from informal settlements to the receiving water bodies and their adjoining wetlands is highly significant. In these instances, the water chemistry of the receiving water bodies is entirely determined by these contributors. Generally, there is limited information with respect to the levels of PBDEs in the aquatic ecosystems within the region where these samples were collected. However, the recent evaluation of the freshwater systems within the Western Cape region with respect to PBDEs implicates wastewater discharges and grey water intrusion as important sources of these pollutants in the investigated river systems (Fatoki et al., 2012; Daso et al., 2013b). Therefore, the female WC populations which spend considerable time foraging on aquatic flora and on small fauna within such wetland ecosystems could preferentially accumulate these pollutants in their body tissues and thus eliminate them via egg laying.

Other factors, including the age of the birds, feeding rate, feed quality, diet composition, amongst others variables, could contribute to the observed inter-species differences in this study. Incidentally, many of these were not considered in the present study. The age of organisms suitable for biomonitoring studies is an important consideration for bioaccumulation tests, however, we can with reasonable confidence say that female birds from both species are at least between 6 and 9 years of age as this is considered the age at which females reach sexual maturity for both species (SGH: Kemp, 1995a; WC: Barnes, 2000; Coverdale, 2001). This factor is correlated to the degree of accumulation of persistent organic pollutants in any test organism. Additionally, their feed quality, 
especially the quality of available water could vary significantly from one location to the other. The combination of these factors can, therefore, have pronounced effects on their feeding rate as well as their metabolic capabilities. Consequently, the observed trend in this study might be a reflection of the cumulative effects of these and other associated factors; but the fact remains that they are being exposed to potentially harmful toxic chemicals contributing to the declining reproductive success of both species.

The non-detection of PBDE-154 in both bird species is very surprising. Considering the fact that this congener is one of the major constituents of the penta- and octa-BDE technical formulations, it is expected that it would be detected in at least some of the analysed samples. Many studies have reported relatively low levels of this congener in eggs of different bird species. Bustnes et al. (2007) found a total percent contribution of less than $5 \%$ for PBDE-154 to the total PBDEs investigated in eggs of Tawny owl in northern Europe. A similar trend was observed in the analysis of different tissues (muscles, liver and kidney) of birds of prey in northern China. The overall mean percent contribution of this congener to the total PBDEs, in all cases, was less than 5\% (Chen et al., 2007). In a related study, this congener had the least number of detection amongst the nine PBDE congeners determined in 10 peregrine falcon eggs collected from the terrestrial ecosystem in Canada. Furthermore, this congener was not detected in any of the two eggs from the same avian species which was collected within the aquatic ecosystem in Canada (Guerra et al., 2012). This probably indicates the preferential metabolism of this congener in some avian species. However, the underlying factors responsible for its non-detection in the eggshells of the birds investigated in this study need further investigation.

\subsubsection{PBDE concentrations in WC eggshells}

The sum PBDEs concentrations in WC eggshell samples ranged from ND to $451.81 \mathrm{\mu g} \mathrm{g}^{-1}$, Iw with a median value of $9.47 \mu \mathrm{g} \mathrm{g}^{-1}$, Iw. PBDEs were detected in all the analysed eggshells, although there was predominance of the lower brominated congeners in nearly all the eggshells, with the exception of one sample where PBDE 183 was the most dominant congener. The pattern assumed by the PBDE congeners in the present study was consistent with the findings from a recent study where highly brominated organic compounds, including octa-, nona- and deca-BDE were reported to be less readily transferred to chicken eggs during egg formation and embryo development (Zheng et al., 2014). In fact, PBDE 154, 153 as well as PBDE 209 were not detected in all the analysed eggshell samples in the present study. The congener pattern of the remaining PBDEs was as follows: PBDE $100>$ PBDE 99 > PBDE 183 > PBDE 17 > PBDE 47. The contribution of the three major congeners of the penta-BDE technical formulation (PBDE 47, 100 and 99) accounted for more than $96 \%$ to the sum PBDEs obtained for the entire WC eggshell samples, thus suggesting the exposure of these birds to local point sources of these pollutants around their nesting sites.

The observed variations in PBDE concentrations, notably amongst the lower brominated congeners, in the individual eggshell sample is quite remarkable. Generally, there exists a sort of disparity with respect to PBDE concentrations in the WC eggshells across the sampling sites. It was observed that the sampling sites (Nottingham Road, Kamberg as well as Underberg) in close proximity to the rapidly 
growing residential development sites, tourism and holiday resort centres within the Kwa-Zulu Natal midlands had significantly high PBDE levels than the sampling sites situated in the remote areas of the study area. Similar observations had previously been reported for PBDEs where elevated levels found in avian eggs were attributed to rapid industrialization (Lam et al., 2008) and proximity of sampling sites to urban centres (Van den Steen et al., 2009). In addition, the observed PBDE variations in the eggshell samples might be a reflection of the unique dietary preferences of the individual bird, especially prior to their laying season. Their exposure to variable levels of these pollutants within the wetlands where these birds forage that are known to receive large quantities of treated and untreated effluents from the adjoining WWTPs could represent additional exposure pathway contributing to the observed variations.

\subsubsection{PBDE concentrations in WC dried albumin materials}

Although, all the WC eggs were successfully hatched, there were still traces of some dried egg membranes containing some dried albumin materials in the eggshells samples. The sum PBDE concentrations obtained for these samples were several orders of magnitude higher than those obtained for the WC eggshell samples. These ranged from 0.27 to $7145.73 \mu \mathrm{g} \mathrm{g}^{-1}$, Iw with a median value of $84.6 \mu \mathrm{g} \mathrm{g}^{-1} \mathrm{Iw}$. A somewhat similar congener pattern (PBDE-100 > PBDE-99 > PBDE-183 > PBDE-17 > PBDE-209 > PBDE-47 > PBDE-153 > PBDE-154) to those observed for the WC eggshell samples was found for the dried albumin samples. In this case, PBDE-209 which was not detected in the eggshell samples was ranked fifth and contributed about $0.78 \%$ to the sum PBDEs of the entire dried albumin samples. On the other hand, the three major representative congeners of the pentaBDE technical formulations (PBDE-47, 100 and 99) contributed more than $85 \%$ to the sum PBDEs.

In addition to the possible underlying factors contributing to the observed variations previously highlighted in sub-section 3.1.1, the Kwa-Zulu Natal Midlands is popular and renowned for its ecotourism potentials. The favourable weather conditions often enjoy throughout the year offer unique opportunities to tourists to visit several nature reserves in different parts of the study area. Besides, the study area also play host to several recreational and sporting events, including golf, cycling, amongst others. During these human-related activities, it is likely that consumer products treated with PBDEs, especially those containing penta-BDE technical formulation might have been carelessly disposed into the environment. Incidentally, there are no major industrial activities that are known to release these chemicals into the environment within the study area except WWTP discharges. As a result, we conclude that activities related to ecotourism might directly or indirectly contribute to the observed variations in the PBDE concentrations in the eggshell samples of the investigated birds.

\subsubsection{PBDE concentrations in SGH eggshell samples}

As shown in Table 2, the sum PBDEs for the SGH samples ranged from ND to $264.17 \mu \mathrm{g} \mathrm{g}^{-1}$, Iw, with a median value of $6.49 \mu \mathrm{g} \mathrm{g}^{-1}$, Iw. Generally, the frequency of PBDE detection vary considerably between the lower and higher brominated congeners. PBDE congeners with less than five bromines were more predominant than those with more bromine substituents. In general, PBDE-154, 183 and 
209 were not detected in any of the analysed SGH samples. However, PBDE-17, 47, 100, 99 and 153 were detected in approximately 56, 56, 33, 56 and $22 \%$ of the analysed SGH samples, respectively. The observed variations in the sum PBDE levels were possibly due to locational differences in the sampling areas. Unlike the WC sampling sites, the SGH eggshell samples were collected in close proximity to coal and copper mining sites with their attendant atmospheric releases of gaseous pollutants. It is, however, not clear whether these mining activities could contribute to PBDE releases into the environment. We suggest that further monitoring studies should be focused on other environmental matrices in this region.

\subsection{Factors potentially influencing PBDE levels in bird species}

Based on the present findings, it is clear that the female WC populations demonstrate unique capacity to accumulate and eliminate certain PBDE congeners via egg laying than the SGH species. Considering the sum of the individual PBDE congener in individual sample of both species, the WC preferentially accumulates PBDE-17, 100 and 99 by a factor of 49,50 and 50 than the SGH, respectively. Only in isolated cases was the reverse the case. In these instances, PBDE-47 and 153 were more accumulated in the SGH by a factor of 14 and 22 than in WC, respectively. These observed variations might be related to specific differences in the biology as well as the ecology of the investigated birds (Lam et al., 2007). For instance, the SGH are predominantly terrestrial while WC forages extensively within wetland environments where bioaccumulation conditions may well be enhanced. The unique differences in the feeding habits of the bird species investigated could explain some of the observed differences in the concentrations of PBDEs measured, although they are both omnivorous. For most avian species, food is regarded as the major intake pathway for PBDEs (Lam et al., 2007). Hence, the occurrence of the higher PBDE congeners, especially PBDE-183 and 209 mostly in the dried albumin of the WC suggest that fish and other aquatic invertebrate consumption may represent their primary exposure pathway to PBDEs.

With growing industrial and agricultural activities, both terrestrial and aquatic avian habitats are increasingly becoming more complex. The possible synergistic effects of complex chemical substances on wild bird populations cannot be over-emphasised. The evaluation of the cumulative effects of highly toxic and persistent organic pollutants such as polychlorinated biphenyls (PCBs), dioxins, furans, organochlorine pesticides, PBDEs, amongst others, in avian habitat is critical, given the fact that these harmful chemicals are commonly detected in different environmental matrices associated with these birds (Quinn et al., 2011; Daso et al., 2013b).

Besides their unique dietary and habitat preferences, other important factors, including migratory behaviours and metabolic capacities may contribute to their inter-species differences (Jasper et al., 2006). Wattled Cranes are largely non-migratory birds, except in rare cases where they respond to seasonal water shortages, however, they do travel fairly large distances between foraging sites and thus cannot be regarded as sedentary or localized and will not reflect conditions associated with a particular habitat.

The SGH, on the other hand, is largely territorial with the entire family group safeguarding their territory which can be anything between 5000 ha in protected areas to 20000 ha in unprotected 
habitats (Theron et al., in press). Furthermore, differences in the rates of uptake, elimination and metabolism of PBDEs by both species could contribute to the observed differences (Malik et al., 2011). The relatively high levels of PBDEs found in the WC samples might be a reflection of their dietary preferences in a more aquatic environment such as the opportunistic consumption of aquatic invertebrates and fish.

\subsection{Possible effects of observed PBDE levels on birds' reproductive success}

The potential changes in reproductive success observed in similar birds exposed to environmentally relevant PBDE levels could offer an explanation to the reproductive behaviours exhibited by the avian species investigated in this study, although it is difficult to establish a clear link in this regard. In the present study, efforts were not focused on determining the number of hatchlings or the reproductive success of the individual nests within the study areas. However, the reproductive trends of both avian species investigated in this study are well documented. For the SGH, two eggs are laid and the chicks hatch asynchronously where the second hatched chick dies of starvation as it is unable to compete with the older chick for food (Kemp 1995b, Knight 1990). Breeding success, even within the conserved KNP, is relatively unsuccessful with an estimated $49 \%$ of breeding attempts fledge one chick and $31 \%$ of fledged chicks reach maturity (Kemp 1988). Breeding success within WC is also poor with only one young reared per pair with an estimated $55 \%$ successful breeding attempts and a $47 \%$ fledgling success for KwaZulu-Natal (Johnson \& Barnes 1991, Tarboton et al. 1987). More recent records are, as yet, unavailable.

To establish a clear link between in ovo PBDE levels and possible reproductive effects in avian species, evidence from similar studies implicating exposure to PBDEs will be highly valuable. Recently, (Gilchrist et al., 2014) reported that the exposure of free-ranging tree swallows to organic contaminants, including PBDEs together with the contributions of other biological factors could cause serious effects on avian reproduction. In their study, the sum PBDEs (PBDE-99, 47, 100, 153 and 154) concentrations of 590.1 and $205.5 \mathrm{ng} \mathrm{g}^{-1} \mathrm{ww}$, possibly corresponding to 39.34 and $16.70 \mu \mathrm{g} \mathrm{g}^{-1}$, Iw (estimated on the assumption that the average egg moisture and lipid contents were 70 and $5 \%$, respectively) were found to influence the timing of egg laying in these birds. Although their study was conducted on whole egg homogenates, the congruity of the congener pattern as well as the comparable PBDE levels with this present study suggest that both WC and SGH could witness similar reproductive effects. This may not be entirely true because different avian species are known exhibit different responsiveness to PBDE exposure. (Winter et al., 2013) observed that in ovo PBDE levels as low as $10 \mathrm{ng} \mathrm{g}^{-1}$ PBDE-99 may affect reproduction in small passerines with reduction in clutch size noted as the most important indicator of exposure to PBDEs. (Fernie et al., 2009) were probably the first researchers to demonstrate cause-and-effects of PBDE exposure on avian reproduction. Their work which examined the possible reproductive effects via the exposure of American Kestrels to 0.12 $\mu \mathrm{g} D \mathrm{D}-71 / \mu \mathrm{l}$ (low-exposure dosage) and $0.65 \mu \mathrm{g} \mathrm{DE}-71 / \mu \mathrm{l}$ (high-exposure dosage) through diet was very significant. Both exposure dosages were found to produce reproductive effects such as delayed egg laying, reduced egg size, eggshell thinning, reduced fertility and reproductive success. These 
observed effects in American kestrel were strongly associated with their rapidly declining population across North America.

To the best of our knowledge, no exposure and risk assessment studies with respect to PBDEs have been conducted on both the WC and SGH species. The evaluation of the potential hazards posed by PBDEs was based on certain assumptions and extrapolations from previous related studies. Therefore, No Observed Effect Concentration/Level (NOEL) or Predicted No Effect Concentration (PNEC) was extrapolated from previous studies on birds of prey. In the American Kestrel, Lowest Observed Effect Level (LOEL) of 1,800 $\mathrm{ng} \mathrm{g}^{-1}$ wet weight (ww) was associated with impaired piping and hatching success (McKernan et al., 2009), while impaired reproduction above a threshold level of $1,000 \mathrm{ng} / \mathrm{g}$ ww for Osprey's was observed (Henny et al., 2009).

In this present study, the estimation of PNEC was based on the approach described by Chen et al. (2010) for the Peregrine falcon where the LOEL was divided by an uncertainty factor of 10 to account for multiple variations. Hazard quotients (HQs) were calculated by dividing the median value of the sum of PBDE concentrations for each species with the PNEC. The results obtained as shown in Table 3 are interpreted as $<0.1$ no hazard, a value between 0.1 and 1.0 as low to moderate hazard and a value $>1$ as a high hazard (Lemly, 1996).

Table 3: Hazard quotients (HQs) of PBDEs for Southern Ground-Hornbill and Wattled Crane species

\begin{tabular}{llccc}
\hline \multicolumn{4}{c}{ Species } \\
\hline Parameters & \multicolumn{2}{c}{ Southern Ground-Hornbill } & \multicolumn{2}{c}{ Wattled Crane } \\
LOEL $(\mathbf{n g} / \mathbf{g}$, Iw) & ${ }^{\mathrm{a}} 112,500$ & ${ }^{\mathrm{b}} 68,870$ & ${ }^{\mathrm{a}} 112,500$ & ${ }^{\mathrm{b}} 68,870$ \\
PNEC $(\mathbf{n g} / \mathbf{g}, \mathbf{l w})$ & 11,250 & 6,887 & 11,250 & 6,887 \\
MEC $(\mathbf{n g} / \mathbf{g}, \mathbf{l w})$ & 6,486 & 6,486 & 311,748 & 311,748 \\
HQs & $\mathbf{0 . 5 8}$ & $\mathbf{0 . 9 4}$ & $\mathbf{2 7 . 7 1}$ & $\mathbf{4 5 . 2 7}$
\end{tabular}

a,b - estimated LOEL for impaired pipping and impaired reproduction based on data from Da Chen et al. 2010 and Henny et al. 2009, respectively; MEC - maximum environmental concentration.

Prior to the estimation of the HQs, certain assumptions were made to correct for the inconsistencies in the adopted LOEL values, which were expressed on wet weight basis. To express these values on lipid weight basis, we assumed that the moisture content in eggs from the studies from which these LOEL values were derived was $60 \%$. More so, the average lipid content for the American kestrel and Osprey eggs were estimated to be 4.00 and $3.63 \%$, respectively. Based on these assumptions, the LOEL values employed for the estimation of HQs for both bird species were expressed on lipid weight basis. In addition, the total PBDE concentrations for both the eggshell and dried albumen were summed up for the individual WC samples, which were thus comparable to the whole eggshell of the $\mathrm{SGH}$ results. These values were then employed for the estimation of HQs. Considering the HQ values obtained for both bird species, it appeared that the WC population was more susceptible to the hazards posed by exposure to PBDEs, as the HQ was 48 times that of the SGH. These findings may be indicative of the potential contributions of PBDEs to the declining population trend of both species. 
Table 4: Comparison of the findings of this study with similar studies conducted across the globe

\begin{tabular}{|c|c|c|c|c|c|c|c|}
\hline $\mathbf{S} / \mathbf{N}$ & Bird species & Location & Sampling year & $\mathbf{N}$ & $\mathbf{N C}$ & Sum PBDE (ng/g, lipid wt.) & References \\
\hline 1. & Grey Heron & Limpopo, South Africa & 2009 & 6 & 10 & 61 & Bouwman et al. (in press) \\
\hline 2. & Cattle Egret & Limpopo, South Africa & $2009 / 10$ & 5 & 10 & 15 & Bouwman et al. (in press) \\
\hline 3. & House Sparrow & Limpopo, South Africa & $2009 / 10$ & 2 & 10 & 2.5 & Bouwman et al. (in press) \\
\hline 4. & Peregrine Falcons & Southern/Northern Sweden & $1987-1999$ & $24 / 18$ & 7 & $39,000^{\mathrm{a}}$ & Lindberg et al., 2004. \\
\hline \multirow[t]{2}{*}{5.} & Forster's tern & San Francisco Bay, USA & 2001 & 29 & 5 & 62,400 & She et al., 2008. \\
\hline & & San Francisco Bay, USA & 2002 & 20 & 5 & 63,300 & She et al., 2008. \\
\hline \multirow[t]{2}{*}{6.} & Caspian tern & San Francisco Bay, USA & 2002 & 20 & 5 & 36,100 & She et al., 2008. \\
\hline & & San Francisco Bay, USA & 2003 & 20 & 5 & 26,300 & She et al., 2008. \\
\hline 7. & Sacred ibis & Parys, South Africa & $2004 / 05$ & 2 & 8 & $61-396^{\mathrm{b}}$ & Polder et al., 2008. \\
\hline 8. & Great Blue Heron & Canada & $2001 / 02$ & NS & 7 & $70.7-1,377^{\mathrm{b}, \mathrm{c}}$ & Champoux et al., 2010. \\
\hline \multirow[t]{3}{*}{9.} & Little Egret & Hong Kong, China & 2004 & 5 & 13 & $140-760^{b}$ & Lam et al., 2007. \\
\hline & & Xiamen, China & 2004 & 5 & 13 & $30-55^{b}$ & Lam et al., 2007. \\
\hline & & Quanzhou, China & 2004 & 5 & 13 & $140-320^{b}$ & Lam et al., 2007. \\
\hline \multirow[t]{3}{*}{10.} & Herring gull & North Norway & 1983 & 10 & 6 & $457^{\mathrm{d}}$ & Helgason et al., 2009. \\
\hline & & & 1993 & 10 & 6 & $759^{d}$ & Helgason et al., 2009 \\
\hline & & & 2003 & 10 & 6 & $570^{\mathrm{d}}$ & Helgason et al., 2009 \\
\hline \multirow[t]{3}{*}{11.} & Black-legged Kittiwake & North Norway & 1983 & 10 & 6 & $144^{\mathrm{d}}$ & Helgason et al., 2009 \\
\hline & & & 1993 & 10 & 6 & $308^{d}$ & Helgason et al., 2009 \\
\hline & & & 2003 & 10 & 6 & $196^{\mathrm{d}}$ & Helgason et al., 2009 \\
\hline \multirow[t]{3}{*}{12.} & Atlantic puffin & North Norway & 1983 & 10 & 6 & $103^{d}$ & Helgason et al., 2009 \\
\hline & & & 1993 & 9 & 6 & $217^{\mathrm{d}}$ & Helgason et al., 2009 \\
\hline & & & 2003 & 10 & 6 & $90^{\mathrm{d}}$ & Helgason et al., 2009 \\
\hline 13. & Common Cormorants & Odiaba, Japan & 1998 & 10 & 20 & $60-3,300$ & Watanabe et al., 2004. \\
\hline 14. & Southern Ground-Hornbill & Limpopo \& Mpumlanga, South Africa & $2012 / 13$ & 9 & 8 & $\mathrm{ND}-264,170^{\mathrm{b}}$ & This study. \\
\hline 15. & Wattled Crane & KwaZulu Natal, South Africa & 2011 & 6 & 8 & $\mathrm{ND}-7,155,730^{\mathrm{b}}$ & This study. \\
\hline
\end{tabular}

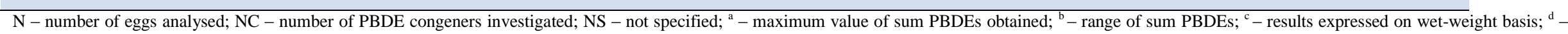
reported mean values. 


\subsection{Comparison with other similar studies}

Regrettably, there were no similar studies conducted elsewhere on similar bird species as investigated in this study. This particularly makes it difficult to establish a clear association with respect to PBDE levels among the bird species using comparative analysis. Nevertheless, the findings from this study were compared with those of Polder et al. (2008), Quinn et al. (2011) and Bouwman et al. (in press) from South Africa and with other related studies across the world. As shown in Table 4, it is evident that extremely high levels of PBDEs (on lipid weight basis) were found in egg samples of the bird species investigated in this study than in other studies conducted across the globe. This is not surprising as most of these studies were carried out using fresh whole egg content, while in this present study, hatched and dried eggshell and albumen samples were employed for the assessment of PBDE levels in the investigated bird samples. Regardless of these assertions, the comparison of the levels of the sum PBDEs in the SGH samples with those of peregrine falcon eggs which exhibit similar dietary preferences with the SGH was made. Generally, the observed levels for $\mathrm{SGH}$ in this study were comparable to those reported for peregrine falcons eggs in most European studies, Spain (160 - $3600 \mathrm{ng} \mathrm{g}^{-1}$, Iw), Sweden (29 - 39,000 ng g ${ }^{-1}$, Iw), Greenland (300 - 12,900 ng $\left.\mathrm{g}^{-1}, \mathrm{Iw}\right)$, and in few instances, higher than those reported in North American studies, Canada (530 $\left.38,000 \mathrm{ng} \mathrm{g}^{-1}, \mathrm{Iw}\right)$, California (80 - 53,100 $\left.\mathrm{ng} \mathrm{g}^{-1}, \mathrm{Iw}\right)$, and Northeastern USA $\left(811-72,000 \mathrm{ng} \mathrm{g}^{-1}, \mathrm{Iw}\right)$ (Lindberg et al., 2004; Vorkamp et al., 2005; Chen et al., 2008; Johansson et al., 2009; Park et al., 2009; Guerra et al., 2012).

Considering the average weight (195 g) of the unhatched WC eggs, it is expected that relatively high lipid content would be found in unhatched eggs than in hatched eggs. Hence, the observed pattern in the comparative assessment of this study with similar studies is indicative of the relatively small extractable lipid content of the analysed eggshell samples. Therefore, the findings of this study do not necessarily imply that the bird species are exposed to higher PBDE levels than in other regions of the world.

\section{Conclusions}

The assessment of PBDE levels in both bird species clearly showed accumulation of the lower PBDE congeners. Incidentally, the higher brominated congeners (PBDE-183 and 209) were only detected in WC samples. In fact, these congeners were mostly detected in the dried albumen of the analysed samples probably reflecting their preferential affinities to the content of the egg samples. With respect to the observed PBDE levels in both bird species, statistical analyses showed that significant intraspecies as well as inter-species differences exist amongst the analysed samples. These observed differences could be attributed to the unique differences in the feeding habits, dietary and habitat preferences, migratory behaviours and metabolic capacities of the investigated birds, amongst others. The evaluation of the estimated hazard quotients (HQs) of PBDEs revealed that the SGH were exposed to low to moderate hazards, while the WC were subjected to high hazards via exposure to PBDEs. Significantly, the reproductive dysfunctions, including impaired pipping, decreased hatching success as well as impaired reproduction, which are associated with exposure to PBDEs are thus 
likely to be more pronounced amongst the WC population than in the SGH population. These observations may contribute to the potential underlying factors causing the declining population of both bird species. Analysis of additional samples is therefore recommended to fully evaluate this potential impact.

\section{Acknowledgements}

The technical assistance offered by the field staff of the Mabula Ground Hornbill Project and the Wattled Crane Recovery Programme in the collection of eggs and egg shell is gratefully acknowledged. The authors would also like to acknowledge the management of Tshwane University of Technology, Pretoria for providing laboratory facilities and other logistics. Finally, the authors would like to acknowledge the University of Pretoria for the Postdoctoral funding offered to AP Daso from the Vice Chancellor's Postdoctoral programme.

\section{References}

Allan, D.G. (2005). Wattled Crane. In: Hockey, P.A.R., Dean, W.R.J. \& Ryan, P.G. (eds) 2005 Roberts - Birds of South Africa, VIlth ed. Trustees of the John Voelcker Bird Book Fund, Cape Town.

Barnes, K.N. (2000). The Eskom red data book of birds of South Africa, Lesotho and Swaziland. Birdlife South Africa, Johannesburg.

Beilfuss, R., Bento, C., Hancock, P., Kamweneshe, B., McCan, K., Morrison, K. \& Rodwell, L. (2003). Water, wetlands and Wattled Cranes: a regional monitoring and conservation program for southern Africa. Proc. Int. Conf. Environmental Monitoring of Tropical and subtropical Wetlands. Okavango Research Center, Maun, Botswana.

Bento, C. M. 2002. The status and prospects of Wattled Crane Grus carunculatus in the Marromeu Complex of the Zambezi Delta. M.Sc. Thesis. University of Cape Town, South Africa.

Bustnes, J. O., Yoccoz, N. G., Bangjord, G., Polder, A., \& Skaare, J. U. (2007). Temporal Trends (1986-2004) of Organochlorines and Brominated Flame Retardants in Tawny Owl Eggs from Northern Europe. Environmental Science \& Technology, 41(24), 8491-8497.

Chen, D., Mai, B., Song, J., Sun, Q., Luo, Y., Luo, X., . . Hale, R. C. (2007). Polybrominated Diphenyl Ethers in Birds of Prey from Northern China. Environmental Science \& Technology, 41(6), 1828-1833.

Chen, D., La Guardia, M.J., Harvey, E., Amaral, M., Wohlfort, K., Hale, R.C., 2008. Polybrominated diphenyl ethers in peregrine falcon (Falco peregrinus) eggs from the northeastern US. Environmental science \& technology 42, 7594-7600.

Chen, D., \& Hale, R. C. (2010). A global review of polybrominated diphenyl ether flame retardant contamination in birds. Environment International, 36(7), 800-811.

Chevrier, J., Harley, K.G., Bradman, A., Gharbi, M., Sjödin, A. and Eskenazi, B. (2010). Polybrominated diphenyl ether (PBDE) flame retardants and thyroid hormone during pregnancy. Environmental Health Perspectives. 118(10): 1444 - 1449.

Coverdale, B. (2001). Midlands news. Crane Crusade Dec 2001:3. 
Daso, A.P., Fatoki, O.S., Odendaal, J.P. \& Olujimi, O.O. (2012). Occurrence of Selected

Polybrominated Diphenyl Ethers and 2,2',4,4',5,5'-Hexabromobiphenyl (BB-153) in Sewage Sludge and Effluent Samples of a Wastewater-Treatment Plant in Cape Town, South Africa. Archives of Environmental Contamination and Toxicology, 62(3), 391-402.

Daso, A.P., Fatoki, O.S., Odendaal, J.P. \& Olujimi, O. O. (2013a). Polybrominated diphenyl ethers (PBDEs) and 2,2',4,4',5,5'-hexabromobiphenyl (BB-153) in landfill leachate in Cape Town, South Africa. Environmental Monitoring and Assessment, 185(1), 431-439.

Daso, A.P., Fatoki, O.S. \& Odendaal, J.P. (2013b). Occurrence of polybrominated diphenyl ethers (PBDEs) and 2,2',4,4',5,5'-hexabromobiphenyl (BB-153) in water samples from the Diep River, Cape Town, South Africa. Environmental Science and Pollution Research, 20(8), 51685176.

del Hoyo, J.; Elliott, A.; Sargatal, J. 1996. Handbook of the Birds of the World, vol. 3: Hoatzin to Auks. Lynx Edicions, Barcelona, Spain.

Douthwaite, R.J. (1974). An endangered population of Wattled Cranes (Grus carunculatus). Biological Conservation 6:134-142.

Eng, M. L., Williams, T. D., \& Elliott, J. E. (2013). Developmental exposure to a brominated flame retardant: An assessment of effects on physiology, growth, and reproduction in a songbird, the zebra finch. Environmental Pollution, 178(0), 343-349.

Fatoki, O. S., Daso, A. P., Odendaal, J. P., \& Olujimi, O. O. (2012). A survey of commonly investigated polybrominated diphenyl ethers(pbdes) and 2, 2', 4, 4', 5, 5'hexabromobiphenyl(bb-153) in sewage sludge samples from four wastewater treatment plants in Cape Town, South Africa. Fresenius Environmental Bulletin, 21(5a): 1239 - 1248.

Fernie, K.J., Shutt, J.L., Letcher, R.J., Ritchie, I.J., Bird, D.M., 2009. Environmentally relevant concentrations of DE-71 and HBCD alter eggshell thickness and reproductive success of American kestrels. Environmental Science \& Technology 43, 2124-2130.

Forsberg, O. (1994). More Ground Hornbills. Tipto/ $32: 7$

Gilchrist, T.T., Letcher, R.J., Thomas, P., Fernie, K.J., 2014. Polybrominated diphenyl ethers and multiple stressors influence the reproduction of free-ranging tree swallows $(<i>$ Tachycineta bicolor $<$ i $>$ ) nesting at wastewater treatment plants. Science of the Total Environment 472, 63-71.

Guerra, P., Alaee, M., Jiménez, B., Pacepavicius, G., Marvin, C., MacInnis, G., Eljarrat, E., Barceló, D., Champoux, L., Fernie, K., 2012. Emerging and historical brominated flame retardants in peregrine falcon $(<i>$ Falco peregrinus $</ i>)$ eggs from Canada and Spain. Environment international 40, 179-186.

Hancock, P.; Motsumi, A.; Borello, W.; Tyler, S.; Evans, S. W. 2003. Botswana Wattled Crane (Bugeranus carunculatus): action plan and report of the Stakeholder Workshop, 6-8 August 2003, Maun, Botswana. BirdLife Botswana \& BirdLife South Africa, Gaborone.

Henny, C. J., Kaiser, J. L., Grove, R. A., Johnson, B. L., \& Letcher, R. J. (2009). Polybrominated diphenyl ether flame retardants in eggs may reduce reproductive success of ospreys in Oregon and Washington, USA. Ecotoxicology, 18(7), 802-813. 
Hockey, P., Dean, W. R. J., \& Ryan, P. (2005). Roberts birds of southern Africa: Trustees of the John Voelcker Bird Book Fund.

IUCN 2013. IUCN Red List of Threatened Species. Version 2013.1. www.iucnredlist.org accessed online on 3 September 2013

Jaspers, V.L.B., Voorspoels, S., Covaci, A., Eens, M.and Schepens, P. (2006). Can predatory bird feathers be used as a non-destructive biomonitoring tool of organic pollutants? Biological Letters. 2: 283 - 285.

Johansson, A.K., Sellström, U., Lindberg, P., Bignert, A., De Wit, C.A., 2009. Polybrominated diphenyl ether congener patterns, hexabromocyclododecane, and brominated biphenyl 153 in eggs of peregrine falcons (Falco peregrinus) breeding in Sweden. Environmental Toxicology and Chemistry 28, 9-17.

Johnson, D. N. and Barnes, P. R. (1991). The breeding biology of the Wattled Crane in Natal. In: JT Harris (ed). Proceedings 1987 International Crane Workshop. pp. 377-386. International Crane Foundation, Baraboo, Wisconsin

Kefeni, K. K., \& Okonkwo, J. O. (2012). Analysis of major congeners of polybromobiphenyls and polybromodiphenyl ethers in office dust using high resolution gas chromatography-mass spectrometry. Chemosphere, 87(9), 1070-1075.

Kemp, M. I. and Kemp, A. C. (1977). Bucorvus and Sagittarius: two modes of terrestrial predation. In: Kemp, A.C. (ed). Proc. Symp. Afr. Predatory Birds, pp. 13-16. Northern Transvaal Ornithological Society, Pretoria.

Kemp, A.C. (1987). Southern Ground Hornbill release programme. EEP Hornbill Taxon Advisory Group Newsletter 3(1):26-28.

Kemp, A. C. (1988). The behavioural ecology of the southern ground hornbill: are competitive offspring at a premium? Proceedings International $100^{\text {th }}$ Deutsche Ornithologen Gesellschaft Meeting. Current topics in avian biology, pp. 267-271.

Kemp, A. C. (1995a). The Hornbills. Bird Families of the World. Oxford University Press, Oxford.

Kemp, A. C. (1995b). The hornbills. Bucerotiformes. pp. 302, Oxford University Press, Oxford

Knight, 1990. Status, distribution and foraging ecology of the Southern Ground Hornbill (Bucorvus cafer) in Natal. Unpublished MSc thesis, University of Natal, Durban.

Kirkegaard, M., Sonne, C., Dietz, R., Letcher, R.J., Jensen, A.L., Stige Hansen, S., Jenssen, B.M. and Grandjean, P. (2011). Alterations in thyroid hormone status in Greenland sledge dogs exposed to whale blubber contaminated with organohalogen compounds. Ecotoxicology and Environmental Safety. 74(1): 157 - 163.

Knight, G.M. (1990). Status, distribution and foraging ecology of the Southern Ground Hornbill (Bucorvus cafer) in Natal. Unpublished MSc Thesis, Univ. Natal, Durban.

Konrad, P.M. (1981). Status and ecology of the Wattled Crane in South Africa. In: Lewis, J.C. (ed). Proc. Int. Crane Symp. Sapporo, Japan.

Lam, J. C. W., Kajiwara, N., Ramu, K., Tanabe, S., \& Lam, P. K. S. (2007). Assessment of polybrominated diphenyl ethers in eggs of waterbirds from South China. Environmental Pollution, 148(1), 258-267. 
Lam, J.C., Murphy, M.B., Wang, Y., Tanabe, S., Giesy, J.P., Lam, P.K., 2008. Risk assessment of organohalogenated compounds in water bird eggs from South China. Environmental science \& technology 42, 6296-6302.

Lema, S.C., Schultz, I.R., Scholz, N.L., Incardona, J.P. and Swanson, P. (2007). Neural defects and cardiac arrhythmia in fish larvae following embryonic exposure to 2,2 ', 4, 4'tetrabromodiphenyl ether (PBDE 47). Aquatic Toxicology. 82(4): 296 - 307.

Lema, S.C., Dickey, J.T., Schultz, I.R. and Swanson P. (2008). Dietary exposure to 2,2',4,4'tetrabromodiphenyl ether (PBDE-47) alters thyroid status and thyroid hormone-regulated gene transcription in the pituitary and brain. Environmental Health Perspectives. 116(12):1694-1699.

Lemly, A. D. (1996). Evaluation of the hazard quotient method for risk assessment of selenium. Ecotoxicology and Environmental Safety, 35(2), 156-162.

Lilienthal, H., Hack, A., Roth-Härer, A., Grande, S. W., \& Talsness, C. E. (2006). Effects of developmental exposure to 2, 2', 4, 4', 5-pentabromodiphenyl ether (PBDE-99) on sex steroids, sexual development, and sexually dimorphic behavior in rats. Environmental health perspectives, 114(2), 194.

Lindberg, P., Sellström, U., Häggberg, L., De Wit, C.A., 2004. Higher brominated diphenyl ethers and hexabromocyclododecane found in eggs of peregrine falcons (Falco peregrinus) breeding in Sweden. Environmental science \& technology 38, 93-96.

Malik, R. N., Moeckel, C., Jones, K. C., \& Hughes, D. (2011). Polybrominated diphenyl ethers (PBDEs) in feathers of colonial water-bird species from Pakistan. Environmental Pollution, 159(10), 3044-3050.

Maozeka, F. (1993). Observations on three pairs of Wattled Crane breeding east of the Great Dyke, Mazowe District. Honeyguide 39:182-188.

Marteinson, S. C., Bird, D. M., Shutt, J. L., Letcher, R. J., Ritchie, I. J., \& Fernie, K. J. (2010). Multigenerational effects of polybrominated diphenylethers exposure: Embryonic exposure of male American kestrels (Falco sparverius) to DE-71 alters reproductive success and behaviors. Environmental Toxicology and Chemistry, 29(8), 1740-1747.

McCann, K.I., Shaw, K., Anderson, M.D. \& Morrison, K. (2001). Techniques for determining movement patterns of Blue and Wattled Cranes in South Africa - colour-ringed versus satellite telemetry. Ostrich Suppl. 15:104-108.

McCann, K. I., \& Benn, G. A. (2006). Land use patterns within Wattled Crane (Bugeranus carunculatus) home ranges in an agricultural landscape in KwaZulu-Natal, South Africa. Ostrich-Journal of African Ornithology, 77(3-4), 186-194.

McKernan, M. A., Rattner, B. A., Hale, R. C., \& Ottinger, M. A. (2009). Toxicity of polybrominated diphenyl ethers (de-71) in chicken (Gallus gallus), mallard (Anas platyrhynchos), and American kestrel (Falco sparverius) embryos and hatchlings. Environmental Toxicology and Chemistry, 28(5), 1007-1017.

Olukunle, O., Okonkwo, J., Kefeni, K., \& Lupankwa, M. (2012). Concentrations of Polybrominated Diphenyl Ethers in Sediments from Jukskei River, Gauteng, South Africa. Bulletin of 
Environmental Contamination and Toxicology, 88(3), 461-466. doi: 10.1007/s00128-011$0481-y$

Park, J.-S., Holden, A., Chu, V., Kim, M., Rhee, A., Patel, P., Shi, Y., Linthicum, J., Walton, B.J., Mckeown, K., 2009. Time-trends and congener profiles of PBDEs and PCBs in California peregrine falcons (Falco peregrinus). Environmental science \& technology 43, 8744-8751.

Pittman, J. M. 2007. Update on the Wattled Crane recovery program, South Africa. Re-introduction News: 17-19.

Rogers, C. \& Rogers, N. (1999). Wattled Cranes north of Beira, Mozambique. Honeyguide 45: 134135.

Tarboton, W.R. (1984). The status and conservation of the Wattled Crane in the Transvaal. In: Ledger, J.A. (ed). Proc. $5^{\text {th }}$ Pan-African Ornithological Congress, pp. 665-678.

Tarboton, W. R., Barnes, P. R. and Johnson, D. N. (1987). The Wattled Crane in South Africa during 1978 - 1982. In: GW Archibald and RF Pasquier (eds). Proceedings 1983 International Crane Workshop pp. 353-361. International Crane Foundation, Baraboo, Wisconsin

Tarboton, W.R. (2001). A guide to the nests and eggs of southern African birds. Struik, Cape Town.

Theron, N., Jansen, R., Grobler, P \& Kotze, A. (in press). The home range of a recently established group of Southern Ground-Hornbill (Bucorvus leadbeateri) in the Limpopo Valley. Koedoe

Van den Steen, E., Pinxten, R., Jaspers, V.L., Covaci, A., Barba, E., Carere, C., Cichoń, M., Dubiec, A., Eeva, T., Heeb, P., 2009. Brominated flame retardants and organochlorines in the European environment using great tit eggs as a biomonitoring tool. Environment International 35, 310-317.

Vernon, C. (1982). Notes from the border - 9. Bee-eater 33:35

Verreault, J., Letcher, R.J., Ropstad, E., Dahl, E. and Gabrielsen. G.W. (2006). Organohalogen contaminants and reproductive hormones in incubating glaucous gulls (Larus hyperboreus) from the Norwegian Arctic. Environmental Toxicology and Chemistry. 25(11): 2990 - 2996.

Verreault, J., Verboven, N., Gabrielsen, G. W., Letcher, R. J., \& Chastel, O. (2008). Changes in prolactin in a highly organohalogen contaminated Arctic top predator seabird, the glaucous gull. General and comparative endocrinology, 156(3), 569-576.

Vorkamp, K., Thomsen, M., Falk, K., Leslie, H., Møller, S., Sørensen, P.B., 2005. Temporal development of brominated flame retardants in peregrine falcon (Falco peregrinus) eggs from South Greenland (1986-2003). Environmental science \& technology 39, 8199-8206.

West, O. (1963). Notes on the Wattled Crane Bugeranus carnunculatus (Gmelin). Ostrich 34:63-77.

Winter, V., Williams, T.D., Elliott, J.E., 2013. A three-generational study of In ovo exposure to PBDE99 in the zebra finch. Environmental Toxicology and Chemistry 32, 562-568.

Zheng, X.B., Luo, X.J., Zeng, Y.H., Wu, J.P., Chen, S.J., Mai, B.X., 2014. Halogenated flame retardants during egg formation and chicken embryo development: Maternal transfer, possible biotransformation, and tissue distribution. Environmental Toxicology and Chemistry. 


\section{Appendix A. Supplementary material}

Supplementary Table 1. The total number of Heterobasidion genes that were considered expressed ${ }^{\mathrm{a}}$ in each of the RNA samples.

\begin{tabular}{lllc}
\hline \multicolumn{1}{c}{ Strain $^{\text {b }}$} & \multicolumn{1}{c}{ Time $^{\mathbf{c}}$} & \multicolumn{1}{c}{ Interaction } & Number of Expressed Genes (\%) \\
\hline A08-5 & 12 & IS incompatible & $11855(88.4)$ \\
A08-25 & 12 & IS incompatible & $11841(88.3)$ \\
A08-48 & 12 & IS compatible & $11326(84.5)$ \\
A08-73 & 12 & IS compatible & $11154(83.2)$ \\
A08-5 & 48 & IS incompatible & $11375(84.9)$ \\
A08-25 & 48 & IS incompatible & $11872(88.6)$ \\
A08-48 & 48 & IS compatible & $10937(81.6)$ \\
A08-73 & 48 & IS compatible & $11292(84.2)$ \\
A08-5 & 96 & IS incompatible & $10359(77.3)$ \\
A08-25 & 96 & IS incompatible & $11628(86.7)$ \\
A08-48 & 96 & IS compatible & $11284(86.7)$ \\
A08-73 & 96 & IS compatible & $11157(83.2)$
\end{tabular}

${ }^{\mathrm{a}}$ Genes were considered expressed if they were detected above had a threshold of 1 count per million $(\mathrm{RPKM}$ values $\geq 0.1)$ and at least 3 unique gene reads mapped to it (Wickramasinghe et al., 2012).

${ }^{\mathrm{b}}$ The strains used in the pairing IS interactions with the tester strain Så 16-4 (see Fig. 1).

${ }^{c}$ Time (hours) after hyphal fusion. 